\title{
Students' Academic Climate Perception Of The School Of Business Of A Mexican University
}

Patricia Valdés-Flores, CETYS Universidad, México

Javier Arturo Campos-Rodríguez, CAVA Investigación Psicología Integral, México

Jorge Sánchez-Franco, CETYS Universidad, México

\begin{abstract}
This paper discusses student perception of the academic climate of the School of Business in a private university in Tijuana, México. With the participation of 257 students out of 348 enrolled in five academic programs, the survey results show that students perceive that the criteria that make up the academic climate occur "Always" in 18\%; $78 \%$ of the criteria occur "Frequently" $2 \%$ of the aspects takes place "Sometimes" and another $2 \%$ of the criteria occurs "Never". There was a significant difference among the results of the nine semesters, while no significant differences were found between the results of the five academic programs and gender analysis. This paper provides information to higher education academic leaders for the design of educational quality improvement strategic actions.
\end{abstract}

Keywords: Academic quality; Students perception; Academic climate

\section{INTRODUCTION}

Tr exican universities emphasize the complement of their educational mission while satisfying the students' needs and making efforts to maintain a dynamic circle of improvement, not only in activities related to the services they offer, but in the academic climate in which the teaching and learning process takes place, because of their interest in quality education and competitiveness.

Quality is the absence of deficiencies (Juran, 1990). Farro describes academic quality as the value added to an educational process or product, in comparative terms, resulting from the relationship between the academic institution's basic internal and external components (Castro and Pérez, 2007).

Hernández Pina, García Sanz and Maquilón Sánchez (2007) point out that learning quality varies or differs as a result of the university students' perception of the academic context and the climate in which the teaching and learning process takes place.

For the purposes of this paper, we will make no distinction between the terms learning quality and academic quality.

Hellriegel, Slocum and Woodman (1999) and Robbins (2004), describe perception as a psychological process in which people gather information from the environment in order to make sense to the world they live in. Gordon, Mondy, Sharplin and Premeaux (1990) describe perception as the way individuals understand or see things in their world.

For individuals, perception is reality (Shepard, 1998), and because of this, it is not important whether perception is accurate or not; after all, perception is what individuals understand and feel as real (Keller, 1999). 
Landázuri Ortiz, Terán Álvarez del Rey, Hernández Cortés and Mercado Doménech (2007) describe the organizational climate as an environmental factor that promotes certain social interactions or organizational dynamics creating an "athomosfere" in a determined situation.

The organizational academic climate is the multidimensional social space conformed by a very complex net of social and psychological interactions among members of an academic community, where processes of educational institutions take place (Landázuri Ortiz, Terán Álvarez del Rey, Hernández Cortés and Mercado Doménech, 2007).

Because of the influence of students' perception of the academic climate on their learning quality (Entwistle, 1987), it becomes the main factor of study in our research that took place in the School of Business of a private university in Tijuana, México.

The purpose of this paper is to advise leaders of higher education institutions by providing information that may contribute to the establishment of strategies oriented to the improvement of quality of the learning process, while creating an academic climate that may satisfy the students' needs.

\section{METHODOLOGY}

\section{Subjects}

The study was held with the participation of $74 \%$ of the student population of the School of Business in a private university in Tijuana, México. There were 257 respondents, out of 348 students registered in Accounting (A), Business Administration (BA), International Business (IB), Marketing (M), and Service Administration (SA) programs offered by the institution. The remaining $26 \%$ of the students did not participate because of their absence during the process.

Forty-three percent of the responders were male and $57 \%$ female.

Nine percent of the participants were Accounting students, $17 \%$ were enrolled in the Business Administration program, $41 \%$ were enrolled in the International Business major, 29\% were Marketing students, and $4 \%$ were enrolled in the Service Administration program.

\section{Instrument}

The Charles F. Kettering School Climate Profile (CFK), an adaptation process to be used in higher education institutions, was applied (González Montesinos, Gallegos Moreno, and Santiago Hernández, 2007).

A 40-item electronic questionnaire in Likert's scale was used in this study. It has four given values $1=$ Never, $2=$ Sometimes, $3=$ Frequently, and 4=Always - to measure the students' perception of the academic climate with a maximum of 160 points.

\section{Procedure}

Through the implementation of .NET Technologies, a data entry system was developed to evaluate the students' perception of the academic climate.

The system consists of a web application using Active Server Page components (ASP) and a Structured Query Language (SQL) Server data bases for capturing each one of the items selected by the students. The student selects one option for each item. Each option has an assigned value in the designed database.

The system allows only one response to assure the responders' veracity.

Once the application is completed and supported by a database searching (Query), the information was concentrated and classified. Using an external application (EXCEL and SPSS), the data were analyzed. 
Once the instructions were given and the questions regarding the instrument were answered, groups of 20 students responded to the survey electronically in the computer lab.

For the inferencial data analysis, $\mathrm{Z}$ and $\mathrm{X}^{2}$ tests were applied, with $\mathrm{p}=.01$ significance level.

\section{RESULTS}

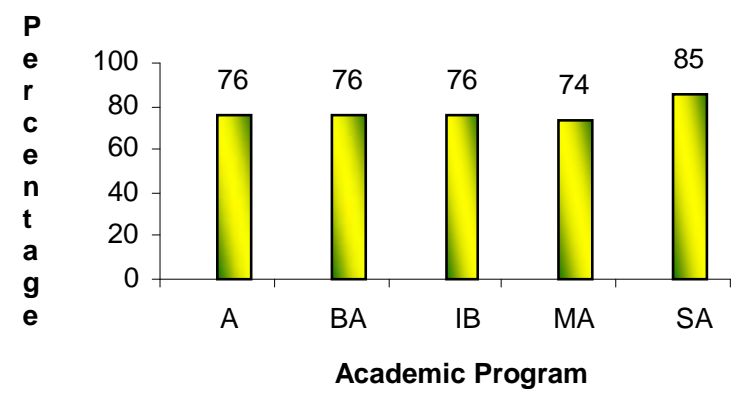

Chart 1: Percentage of Students' Academic Climate Perception by Program

Chart 1 expresses the percentage of the students' perception of the academic climate by program. Accounting, Business Administration and International Business students perceive that the academic climate reaches $76 \%$ of their expectations, while the Marketing Administration program students perceive it happens at $74 \%$, and the Service Administration program students perceive it at $85 \%$.

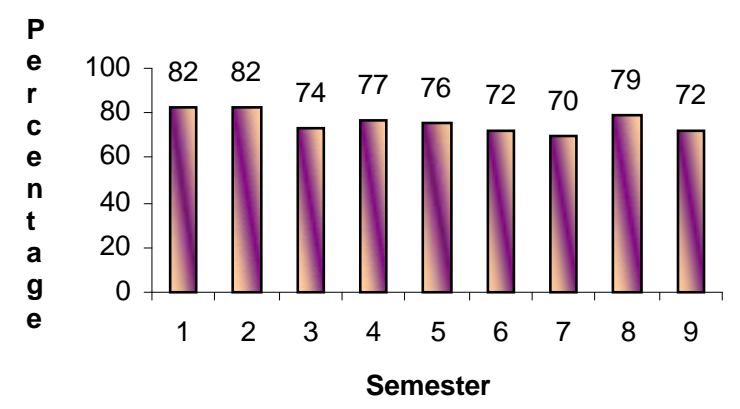

Chart 2: Percentage of Students' Academic Climate Perception by Semester

Chart 2 expresses the percentage of the students' perception of the academic climate by semester. Students enrolled in the first and second semesters perceive that the academic climate reaches $82 \%$ of their expectations; third semester students perceive it occurs at $74 \%$; fourth semester students perceive it at $77 \%$; fifth semester students perceive it at $76 \%$, sixth and ninth semester students perceive it at $72 \%$; seventh semester students perceive it at $72 \%$, and eight semester students perceive it at $79 \%$.

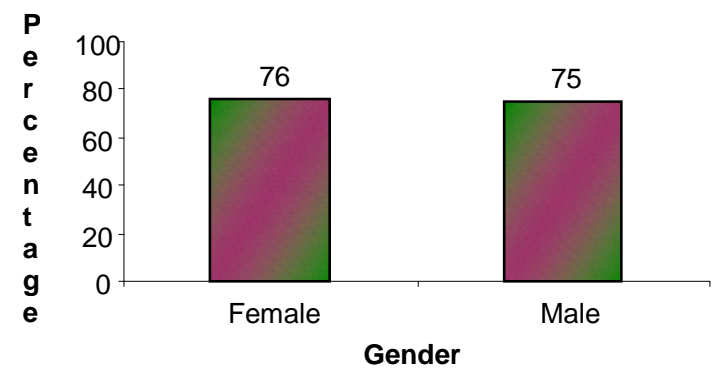

Chart 3: Percentage of Students' Academic Climate Perception by Gender 
Chart 3 expresses the percentage of the students' perception of the academic climate by gender. Female students perceive that the academic climate reaches $76 \%$ of their expectations, while male students perceive it at $75 \%$.

'Always' and 'Frequently' are the most common responses, which represent $18 \%$ and $78 \%$, respectively, in terms of the students' perception of the academic climate.

The students perceive that one aspect occurs only 'Sometimes', and another aspect - 'Never' - occurs, which represents $2 \%$ for each situation.

The statistical analysis reflects a significant difference $(\mathrm{p}=.01)$ between the results among the nine semesters, while no significant differences were found among the results of the five programs and gender analysis.

\section{DISCUSSION AND CONCLUSIONS}

In general terms, the results of the study show that students perceive the criteria that make up the academic climate for the programs offered by the School of Business to take place 'Always' or 'Frequently'.

The students enrolled in Accounting, Business Administration and International Business programs show similar appreciations of the school's academic climate; the perception slightly decreases with Marketing Administration students and shows a significant growth in Administration of Service students.

Female and male students had a similar perception of the school's academic climate.

First and second semester students of all programs have a more positive perception of the school's academic climate than students from the rest of the semesters.

Apparently, while the students move forward in their academic program, ups and downs occur in academic climate perception.

It is worth mentioning that the best performing criteria were those related to professors' greater interest in attending classes promptly in relation to the students. The students prefer to be enrolled in their school more than any other one and they perceive most people in their school to be kind.

On the other hand, the criteria that were rated the poorest were those involving decision-making participation; that is, the aspects that have to do with the fact that students are aware of important school matters that affect them and feel they should be included in the discussions before such decisions are made, making sure that students, faculty and administrative personnel input is taken into account.

Evidence of academic climate perception research is scarce in Mexican higher education institutions, which is why it is difficult to establish a benchmark. However, while this study does not present the effective climate as such, it does approach aspects related to the role of faculty, which López Bravo, Vivanco Skarneo y Mandiola Cerda (2006) report, finding that the majority of the subjects in their study were satisfied with the effective climate, even though they noticed some problems related with professors' attitudes toward "less qualified" students who perceive them as "distant" or "less human than expected". Fernández Rodríguez (2007) found in his evaluation of some elements that faculty and administrative personnel perceived themselves being part of the university and that the participants achieved a lower level of satisfaction than expected. The perception of comfort in the university was as expected. In a similar vein, the results of the present study partially confirm his initial hypothesis that students express high expectations, which tend to become lower during their first academic year.

\section{CONCLUSIONS}

Relevant information is provided by the students in regard to the academic climate they perceive in their school. We can highlight the fact that students perceive that only sometimes the most important decisions in the 
school are made in agreement among students, faculty and administrative personnel and that they never become aware of issues and participate in the discussions when important decisions are to be made regarding the performance of the school.

The results provide information to allow the leadership of higher education institutions to determine strengths and weaknesses in the academic climate of their institution, information that facilitates strategy formulation and the establishment of criteria for future improvement programs.

\section{AUTHOR INFORMATION}

Dr. Patricia Valdes Flores. Professor and Coordinator of Business Administration Program, CETYS University. $\mathrm{PhD}$ in Psychology and Master Degree in International Administration, CETYS University, Tijuana, Mexico. Lecturer in various conferences throughout Latin America and Europe. Has published on topics such as leadership, job satisfaction and productivity and teamwork. Third place in Research category of 2009 FIMPES Award, with paper "Students' Perception of the academic climate in business programs in a private university". Best Paper Award in The European Applied Business Research Conference 2007. Academic Certification since 2003 to date, by The National Association of Accounting and Administration Schools (ANFECA), Mexico. Member of Phi Beta Delta Honor Society.

Dr. Javier Arturo Campos. Undergraduate and graduate programs Professor and General Director for CAVAIPI. Publications include "Personal Skills Job Satisfaction and Productivity in Members of High Performance Teams", "The College Teaching Methods and Styles Journal", "An Integral-Interactive-Educational Model for Forming Leaders Through Self-learning Applied to High School Students", "Job Satisfaction and Productivity: Supervisors" and Subordinates' Perception" as well as "Journal: Psychology Teaching and Research". Member of The International Institute of Informatics and Systemic. Best Paper Award, presented in The European Applied Business Research, 2007, Padua, Italy.

Jorge Iván Sánchez Franco. Computer programmer acquainted on system development implementing different design patterns and object-oriented programming. Involved in developing using Win Forms, Web Services, Windows Services, WCF, ASPX, Javascript, SQL Server 2005 and various tools capable of enable an agile and appropriate development according to the different needs.

\section{REFERENCES}

1. Castro Medina, E. y Pérez Kuga, M. I. (2007). Calidad y Tendencia de la Aptitud Académica de los Ingresantes a la Universidad Nacional de San Martín: 1982-1996. Retrieved on October 9, 2007, from

2. http://www.fao.org/ag/AGL/agll/rla128/UNSM/unsm42/unsm42.htm.

3. Farro C., F. (1995). Gerencia de Centros Educativos Hacia la Calidad Total. Editores Asesores Bibliográfico, RG, S.R.L. Lima, p.12.

4. Fernández Rodríguez, M. C. (2007). Expectativas de Satisfacción y satisfacción obtenida en un grupo de estudiantes de nuevo ingreso de la UPR en Cayey. Retrieved on October 15, 2007, fom http://www.cayey.upr.edu/book/export/html/224

5. González Montesinos, M. J., Gallegos Moreno, R. H. y Santiago Hernández V. G. (2007). La Percepción del Ambiente Académico a Nivel Medio Superior: Adaptación de un Instrumento Diagnóstico. INVURNUS - Revista de Investigación de la Unidad Regional Norte de la Universidad de Sonora, Vol. 2 No. 4. Hermosillo, Son.

6. Gordon, J. R., Mondy, R. W., Sharplin, A. \& Premeaux, S. R. (1990). Management and organizational behavior. Boston, EE. UU.: Allyn and Bacon.

7. Hellriegel, D., Slocum, J. W. \& Woodman, R. W. (1999). Comportamiento organizacional. (8 $8^{\mathrm{a}}$ ed.). México D.F.: Thomson.

8. Hernández Pina, F., García Sanz, M. P. y Maquilón Sánchez, J. (2007). Análisis del Cuestionario de Procesos de Estudio-2 Factores de Biggs en Estudiantes Universitarios Españoles. No. 6 / Campo abierto, Revista Fuentes. Retrieved on October 2, 2007 from http://www.revistafuentes.org/htm/article.php?id_volumen=6\&id_article=86 
9. $\quad$ Hodgetts, R. M. (1987). Modern human relations at work. (3 ${ }^{\mathrm{a}}$ ed). New York, EE. UU.: The Dryden Press.

10. Juran, J. M. (1990). Liderazgo para la Calidad. Manual para Ejecutivos. Ediciones Díaz de Santos, S.A. Madrid.

11. Keller, M. A. (1999). Leadership Perception. The Police Chief, 66, (3), 72-73.

12. Landázuri Ortiz, A. M., Terán Álvarez del Rey, A., Hernández Cortés, M. G. y Mercado Doménech, S. J. (2007). Propuesta de Inserción de los Procesos Relativos a la Interrelación Entorno Comportamiento en el Currículum de Niveles Medio Superior.

13. Memoria del I Foro Nacional sobre la Incorporación de la Perspectiva Ambiental en la Formación Técnica y Profesional. Retrieved on October 2, 2007 from http://ambiental.uaslp.mx/foroslp/cd/M-LandazuriYetal021013.pdf

14. López Bravo, I. M., Vivanco Skarneo, Z. y Mandioca Cerda, E. (2006). Percepción de los alumnos sobre su primer año de Universidad: Facultad de medicina Universidad de Chile. Educ. Méd., Barcelona, v. 9, n. 3, pp. 31-37, 2006. Retrieves on October 15, 2007 from

http://scielo.isciii.es/scielo.php?script=sci_arttext\&pid=S1575-18132006000300006\&lng=pt\&nrm=iso

15. Robbins, S. P. (2004). Comportamiento organizacional. (10ª ed.). Naucalpan de Juárez, Edo. de México: Pearson/Prentice-Hall.

16. Shepard, S. (1998). Perception is reality: Perception of employment characteristics of women in administration. Advancing Women in Leadership Journal, 1, (3) (1998, Summer). 